\title{
ESCRAVIDÃO CONTEMPORÂNEA NO CAMPO E CIDADES: UM RETRATO DE MINAS GERAIS ENTRE 2000 A $2015^{1}$
}

\section{Contemporary slavery in the country and towns: a portrait of Minas Gerais from 2000 to 2015}

\author{
Cleiton Ferreira dos Santos \\ Pesquisador no Núcleo de Estudos e Pesquisas Regionais e Agrário - NEPRA-UNIMONTES \\ cleitongeografia22@gmail.com \\ Gustavo Henrique Cepolini Ferreira \\ Professor no Depto. de Geociências - UNIMONTES \\ gustavocepolini@usp.br
}

Artigo enviado para publicação em 14/01/2018 e aceito em 14/06/2018

DOI: $10.12957 /$ tamoios.2018.32238

\section{RESUMO}

A escravidão é considerada um fenômeno social e territorial que emerge nos primórdios das civilizações antigas, que empregavam o trabalho escravo para a execução de tarefas mais pesadas e rudimentares. No entanto, no decorrer da história, e na contemporaneidade, pode-se encontrar inúmeras práticas análogas à escravidão. Diante do exposto, estabeleceu-se como objetivo geral estudar o contexto que envolve o trabalho escravo contemporâneo em Minas Gerais, entre o período de 2000 a 2015, para tal visa-se discutir a situação de Minas Gerais diante das ocorrências de trabalho escravo. Salienta-se ainda, que a maioria das ocorrências tem origem no campo, devido a fatores socioeconômicos em função da contrarreforma agrária em vigor no país. A abordagem metodológica consistiu em pesquisa bibliográfica, tratamento de dados oriundos do Ministério do Trabalho e Emprego e da Comissão Pastoral da Terra, elaboração de mapas, gráficos e tabelas. Assim, é possível inferir que o trabalho escravo contemporâneo infringe as legislações e desencadeia um processo perverso na frente pioneira e em outras regiões do Brasil, respaldado especialmente pelos mecanismos de acumulação primitiva, os quais são incorporados à reprodução ampliada do capital. Por fim, os resultados demostram que nos últimos anos, o número de ocorrências envolvendo trabalhadores em situação de escravidão no Brasil tem diminuído, enquanto que em Minas Gerais constata-se um significativo aumento dos trabalhadores escravos, tanto no campo quanto nos centros urbanos.

Palavras-chave: Trabalho Escravo; Minas Gerais; Território; Leis Trabalhistas; Conflitos.

\section{ABSTRACT}

Slavery is considered a social and territorial phenomenon that emerges in the beginnings of the ancient civilizations, which used slave labor to perform heavier and rudimentary tasks. However, throughout the history and in the contemporaneity one can find innumerable practices analogous to the slavery. Thus, it was established as a general objective to study the context that involves contemporary slave labor in Minas Gerais, between the periods from 2000 to 2015, to discuss the situation of slave labor occurrences in Minas Gerais. It should be noted that most of the occurrences have origin in the field, due to socioeconomic factors that afflict the field owing the agrarian counter-reform in force in the country. Methodological approach consisted of bibliographical research, data processing through the Ministério do Trabalho e Emprego (Ministry of Labor and Employment) and of Comissão Pastoral da Terra (Pastoral Land Commission), elaboration of maps, charts and tables. Thus, it is possible to infer that contemporary slave labor violates work laws and triggers a perverse process on the pioneer front and in other regions of Brazil, especially supported by primitive accumulation mechanisms, which are incorporated into the expanded reproduction of capital. Finally, the results show that in recent years, the number of occurrences involving workers in situations of slavery in Brazil has decreased, while Minas Gerais shows a significant increase in slave labor both in the countryside and in urban centers.

Keywords: Slave labor; Minas Gerais; Territory; Work laws; Conflicts. 


\section{INTRODUÇÃO}

A Organização das Nações Unidas (1948) indica categoricamente que todos os homens nascem livres e iguais em dignidade e direitos. "Todas as pessoas têm direito ao trabalho, à livre escolha do trabalho, a condições equitativas e satisfatórias de trabalho e à proteção contra o desemprego". Nesta mesma declaração é ressaltado que todos aqueles que trabalham têm direito a uma remuneração equitativa e satisfatória, que lhes permita a existência própria e familiar precedida da dignidade humana, e por todos os outros meios de proteção social.

A dignidade é, assim, considerada um fundamento base na vida do homem, a participação do homem na sociedade garante a ele que seus direitos sejam assegurados, ou seja, todo ser humano é digno de seus direitos. Porém, no Brasil nem todos os indivíduos têm seus direitos respeitados. A violação dos direitos a qual precede nosso estudo está, sobretudo, relacionada com a prática do trabalho escravo contemporâneo.

Do ponto de vista econômico, a relação de trabalho escravo é tão lucrativa e vantajosa para os empresários e latifundiários que, infelizmente, é possível ser encontrada em todas as regiões do Brasil em diversas atividades econômicas, tanto no campo quanto nas cidades.

Dito isso, ressalta-se que a escravidão abolida, em tese, no ano de 1888 com a Lei Áurea $^{2}$ persiste no devir histórico brasileiro de maneira perversa. $\mathrm{O}$ trabalho escravo é considerado uma das piores tormentas que o próprio homem impõe sobre o outro; é o esmagamento do homem, constituído pela perda da dignidade do direito à liberdade; é a forma mais primitiva do homem/ de extorquir a força do outro.

Martins (1995) tece uma análise fecunda sobre as relações sociais que compõem a escravidão no Brasil. Para esse autor, a escravidão por dívida é variação extrema do trabalho assalariado em condições de superexploração, ou seja, a exploração dos trabalhadores é elevada ao limite para assegurar sua própria sobrevivência. Trata-se, portanto, de um mecanismo de acumulação primitiva incorporado ao processo de reprodução ampliada do capital ${ }^{3}$.

Nesse devir, nota-se que a Lei de Terras de $1850^{4}$ representa os interesses de fazendeiros e comerciantes ao garantir a continuidade da exploração da força de trabalho mesmo que o cativeiro entrasse em evidente colapso (MARTINS, 1986).

O trabalho escravo é uma ação social opressiva, que desde os primórdios da história da humanidade até a contemporaneidade pode ser visto nas mais remotas sociedades. Neste sentido, as análises de escravidão contemporânea foram baseadas nos conceitos e reflexões de instituições que combatem e denunciam o trabalho escravo no Brasil, tais como: Comissão Pastoral da Terra (CPT) e Organização Internacional do Trabalho (OIT), instituições não governamentais e o Ministério de Trabalho e Emprego (MTE), de cunho governamental.

A conversão $n^{\circ} 29$ da OIT define como trabalho forçado ou obrigatório todo trabalho que precede de ameaças e qualquer penalidade sem livre e espontânea vontade do indivíduo. Já para a CPT (2003), a classificação de trabalho escravo pode ser analisada como o cerceamento à liberdade do trabalhador, provido por mecanismo de endividamento ou por distorção da força por meio de intimidação, espancamento, isolamento, etc.

Além disso, a CPT usa a expressão "superexploração" para indivíduos que são submetidos a trabalhar em situações precárias tanto em relação à renumeração quanto ao ambiente, seguida por infrações graves nas legislações trabalhistas. Almeida (2017) ao analisar o trabalho escravo contemporâneo indica que é uma categoria eminentemente 
política, ou seja, trata-se de um campo de disputas entre uma gama de sujeitos sociais com diversos e antagônicos interesses. Na sequência, a classificação utilizada pelo MTE para definir o trabalho escravo constitui-se no aparato definido pelo Código Penal Brasileiro. Para ser mais preciso, no Brasil, o trabalho escravo é definido pelo Artigo 149 da Lei $n^{\circ}$ 2848/40 do Código Penal, alterado através da Lei ${ }^{\circ}$ 10.803, de 11 de dezembro de 2003, da seguinte maneira:

\begin{abstract}
Art. 149. Reduzir alguém a condição análoga à de escravo, quer submetendoo a trabalhos forçados ou a jornada exaustiva, quer sujeitando-o a condições degradantes de trabalho, quer restringindo, por qualquer meio, sua locomoção em razão de dívida contraída com o empregador ou preposto. Pena - reclusão, de dois a oito anos, e multa, além da pena correspondente à violência.
\end{abstract}

A escravidão contemporânea não envolve necessariamente a mão de obra adulta, mas também a exploração de mão de obra infantil, de modo que o preço do trabalho da criança pode ser inferior ao de um adulto, ou, até mesmo, ocorrer por troca de alimentos, exploração sexual ou constante endividamento. Salienta que essa sujeição física ou psicológica de um homem por outro é agravada no contexto brasileiro através de um instrumento comum, ou seja, as dívidas crescentes e impagáveis.

Nesse contexto, cabe inferir que a escravidão tanto nos campos quanto nas cidades persiste sob diferentes formas. Oliveira (1994) indica que a luta pela terra e liberdade tem feito esses trabalhadores migrarem para outras regiões em busca de trabalho livre e terras libertas. Assim, a peonagem ou "trabalho escravo" expresso pelo autor, em geral, remete ao contexto em que os trabalhadores escravos possuem praticamente as mesmas características: são trabalhadores migrantes, por motivo de expulsão, no sentido da deficiência econômica e da ausência de trabalho, saúde e educação na região de origem, de Índice de Desenvolvimento Humano precário, fazendo com que as pessoas procurem outros lugares para sobreviver.

E, em muitas das vezes, esses trabalhadores são atraídos por falsas promessas de aliciadores, conhecidos como "gatos", que redistribuem aos trabalhadores falsas promessas de emprego com salários, hospedagem, alimentação e transporte. Em muitas dessas circunstâncias o trabalho escravo no campo está relacionado ao processo denominado “escravidão por dívida". Martins (1986) aponta que, nesse processo, o patrão alicia os trabalhadores, fazendo com que esses assumam as dívidas, já manipuladas com taxas cambiais, juros pelo adiantamento do salário e por armazém do próprio patrão, impossibilitando o trabalhador de quitar sua dívida e de sair do trabalho.

De acordo com a Comissão Pastoral da Terra, desde 2000 a 2015 a região Norte do Brasil vem atingindo o recorde em ocorrência de trabalho escravo no campo brasileiro. Os estados do Pará e Tocantins possuem a maior incidência. Ainda de acordo com os dados sistematizados pela CPT, no Centro-Oeste, Nordeste e Sudeste as ocorrências são bastante constantes. Portanto, desde o Sul ao Norte do país essa problemática é encontrada.

Nota-se que a maioria das ocorrências está territorializada no campo. De acordo com a OIT (2010), essa situação justifica-se em função da pobreza e concentração de terras fundiárias; pode-se acrescentar, ainda, o avanço do agronegócio e a fragilidade nas ações de fiscalização.

A partir desse propósito, os dados do CPT revelam que alguns casos de trabalho escravo podem ser encaminhados como casos de extrema violência envolvendo agressão, ameaça de morte, mortes, entre outros. 
Neste contexto, o estado de Minas Gerais apresenta-se como território da escravidão histórica. Por isso, salienta-se que, embora os conflitos envolvendo os trabalhadores escravos tenham diminuído no Brasil, Minas Gerais tem liderado o ranking nacional em casos de trabalhadores em situação análoga à escravidão tanto no campo como nas cidades. Para isso, analisamos a mesorregião Norte de Minas tomando como referência os casos envolvendo trabalhos escravos, os quais chegam à marca de $12 \%$ na escala estadual.

Diante do exposto, surgem as seguintes indagações: $O$ que é a escravidão na contemporaneidade? Entre o período de 2000 a 2015 quantos trabalhadores escravos foram resgatados em Minas Gerais? Quais são os municípios que apresentaram incidência de escravidão em Minas Gerais? Quais atividades econômicas estão envolvidas no trabalho escravo em Minas Gerais e na região Norte de Minas? Quais são as iniciativas tomadas pelo governo diante desse cenário?

Em busca de uma resposta, estabeleceu-se como objetivo geral analisar e mapear o contexto que envolve o trabalho escravo contemporâneo no território de Minas Gerais, entre o período de 2000 a 2015. Já como objetivos específicos: apresentar algumas discussões acerca do posicionamento de Minas Gerais diante das ocorrências de trabalho escravo, assim como verificar a espacialização desses dados na mesorregião Norte de Minas a partir dos conflitos territoriais e trabalhistas predominantemente no campo, envolvendo atividades como: carvoaria, eucalipto, lavoura de sementes, etc.

Para concretizar tais análises apresenta-se um panorama do Brasil baseado nos dados da $\mathrm{CPT}^{5}$ e MTE a partir da Lei de Acesso à Informação. Assim, os mapas e demais leituras fomentam um escopo sobre a situação hodierna do trabalho escravo no país, bem como a constituição perversa e contraditória de uma - "Geografia do Trabalho Escravo".

\section{AS LEGISLAÇÕES TRABALHISTAS BRASILEIRAS: ALGUMAS ANÁLISES}

Após 129 anos da formalização da abolição da escravatura no Brasil, ainda se encontra no país uma quantidade massiva de trabalhadores escravos, em diferentes de formas e contextos. Para Figueira e Prado (2014), o trabalho escravo contemporâneo é um problema maior que se manifesta no sistema capitalista, sendo uma problemática que vem se tornando cada vez questionada na sociedade, devido ao fato do uso compulsório da força de trabalho.

Martins (1986) aponta que, o modo de produção historicamente gerada pela força de trabalho forçado transfigurado em renda capitalizada, a utilização engendrada da força do de trabalho, neste sentido, a condição análoga à de escravo é considerado crime. Essa leitura de Martins, explica-se justamente na figura do fazendeiro, cujo capital estava investido na pessoa do escravo, ou seja, estava imobilizando-o como renda capitalizada, leia-se: tributos pagos aos traficantes e demais comerciantes na expectativa de ganhos futuros, entre outras estratégias mediadas pela tríade: escravo, terra e capital.

No Brasil, o trabalho escravo é definido pelo Artigo 149 da Lei $\mathrm{n}^{\circ}$ 2848/40 do Código Penal, alterado através da Lei ${ }^{\circ} 10.803$, de 11 de dezembro de 2003, da seguinte maneira:

Art.149. Reduzir alguém a condição análoga à de escravo, quer submetendo-o a trabalhos forçados ou a jornada exaustiva, quer sujeitando-o a condições degradantes de trabalho, quer restringindo, por qualquer meio, sua locomoção em razão de dívida contraída com o empregador ou preposto. Pena - reclusão, de dois a oito anos, e multa, além da pena correspondente à violência. 
Diante do exposto, o trabalho que envolva o indivíduo a condição análoga à de escravo é considerado crime, cujos critérios que classificam o indivíduo a estar nessa condição estão relacionados com o tratamento que o empregador oferece ao trabalhador:

\footnotetext{
I - cerceia o uso de qualquer meio de transporte por parte do trabalhador, com o fim de retê-lo no local de trabalho.

II - mantém vigilância ostensiva no local de trabalho ou se apodera de documentos ou objetos pessoais do trabalhador, com o fim de retê-lo no local de trabalho.

$\S 20$ A pena é aumentada de metade, se o crime é cometido.

I - contra criança ou adolescente

II - por motivo de preconceito de raça, cor, etnia, religião ou origem. (BRASIL, 2003)
}

A Carta Internacional dos Direitos Humanos (1948) é considerada o fundamento principal das Nações Unidas, na qual, é constituída pela Declaração Internacional do Direito do Homem, pelo Pacto Internacional sobre os Direitos Sociais, Econômicos e Culturais, além disso, pelo Pacto Internacional sobre os Direitos Civis. O artigo $1^{\circ}$ da Declaração Universal dos Direitos Humanos enuncia que, todos os homens nascem livres e iguais em dignidade e direitos.

Da mesma forma, o artigo $4^{\circ}$ declara que, "ninguém pode ser mantido em escravidão ou em servidão; a escravatura e o comércio de escravos, sob qualquer forma, são proibidos" (ONU, 1948). As leis trabalhistas brasileiras também defendem o fato do trabalho escravo ser crime e proibido no país. Neste sentido, o artigo $23^{\circ}$ da referida declaração exalta que, "toda a pessoa tem direito ao trabalho, à livre escolha do trabalho, a condições equitativas e satisfatórias de trabalho e à proteção contra o desemprego" (ONU, 1948). São direitos fundamentais que o ser humano necessita para exercer seu trabalho, ou seja, todos têm direito, sem discriminação alguma, a salário igual por trabalho igual.

Neste sentido, é ressaltado que, todos aqueles que trabalham têm direito a uma remuneração equitativa e satisfatória, que lhes permita e à sua família uma existência conforme com a dignidade humana, e completa, se possível, por todos os outros meios de proteção social. Muitas das vezes o trabalho escravo contemporâneo está relacionado com a superexploração do trabalho, quando ultrapassa o tempo limite de horas trabalhadas, no entanto, de acordo com o artigo $24^{\circ}$ da Carta Internacional dos Direitos Humanos: "Toda a pessoa tem direito ao repouso e aos lazeres e, especialmente, a uma limitação razoável da duração do trabalho e a férias periódicas pagas" (ONU, 1948). Quando esse direito é violado o empresário ou empregador é submetido à penalidade, de acordo com o Código Penal art. 149 - Lei 2848/40.

Conforme Sakamoto (2006, p.114): "Há leis que, uma vez aprovadas, poderão contribuir para a erradicação do trabalho escravo, como a proposta que prevê o confisco de terras em que esse crime foi flagrado e o aumento da pena mínima para o crime de trabalho escravo". Dessa maneira, dever-se-ia cumprir tais legislações e punir os responsáveis.

Por isso, reafirma-se que o cativeiro segue vigente na realidade de muitos trabalhadores no país, seja nas atividades agropecuárias ou como delimitado em algumas políticas públicas, ou seja, nas atividades laborais urbanas e rurais. Assim,

[...] percebemos a besta fera presente no cotidiano destes trabalhadores, personificada, arrisco em dizer, ora na bancada BBB, ou bancada da Bala, do 
Boi e da Bíblia, responsável pelo lobby no Congresso Nacional para que seja alterado o conceito de trabalho escravo, como vimos. Ou mesmo, arrisco-me novamente em apontar, personificada em um Estado ausente, conivente e condescendente com a prática da escravidão, já que não garante aos órgãos competentes as condições necessárias para dar continuidade ao trabalho de fiscalização e resgate dos trabalhadores. Não há, ainda, o que se comemorar ou celebrar, há sim muito trabalho a ser feito e demônios a serem exorcizados. (MELO e SILVA, 2016, p. 124)

A prática do trabalho escravo está, sobretudo, envolvida em lucros à custa da exploração do trabalhador, do ponto de vista econômico, a relação de trabalho escravo é tão lucrativa e vantajosa para os empresários, que é possível ser encontrado em diversas atividades econômicas, tanto em áreas urbanas quanto em rurais. É necessário discutir e entender a forma pela qual esses trabalhadores são submetidos à condição análoga à de escravo. Neste sentido, podem ser avaliadas pessoas cujos direitos são violados na perda da dignidade ou da liberdade, consequentemente são reduzidas a mero objeto, podendo a chegar à grave risco à sua integridade ou mesmo à sua vida.

A denominação feita pela CPT (2003, p.138) considera o trabalho escravo como a sujeição do trabalhador, podendo estar sujeito à distorção física como também psicológica "o cerceamento da liberdade, seja através de mecanismos de endividamento, seja pelo uso da força (proprietários ou funcionários armados, ocorrência de assassinatos, espancamentos, e práticas de intimidação)".

Dessa maneira, salienta-se que a Comissão Pastoral da Terra - CPT é uma instituição não governamental que trabalha principalmente no registro, acompanhamento e mobilização frente os conflitos no campo brasileiro e na luta pela reforma agrária.

O Ministério do Trabalho e Emprego - MTE e a Comissão Pastoral da Terra - CPT utilizam os mesmos critérios que classificam o indivíduo a condição análoga à de escravo, pelo Artigo 149 da Lei no 2848/40 do Código Penal.

No tocante à Constituição Federal pode-se verificar que a mesma condena o trabalho forçado, ao deliberar como princípios da República Federativa do Brasil: "a dignidade da pessoa humana" (art. $1^{\circ} \mathrm{CF}$, III) e "os valores sociais do trabalho e da livre iniciativa" (art. $\left.1^{\circ} \mathrm{CF}, \mathrm{IV}\right)$; "prevalência dos direitos humanos" (art. $4^{\circ} \mathrm{CF}$, II); na qual, prevalecem os direitos das relações internacionais. Além disso, no (art. $5^{\circ} \mathrm{CF}$, III); estabelece a "garantia de que ninguém será submetido à tortura nem a tratamento desumano ou degradante". Neste sentido, é constituído o direito da liberdade para o exercício de qualquer trabalho, ofício ou profissão, atendidas as qualificações profissionais estabelecidas em leis (art. 5º XIII) (BRASIL, 1988).

Nesse mesmo sentido, ressalta-se o artigo 197 do Código Penal, ao indicar que: "constranger alguém, mediante violência ou grave ameaça". Enquanto no Art. 203 apregoa que: "Frustrar, mediante fraude ou violência, direito assegurada pela legislação do trabalho". Assim como constam algumas medidas envolvendo detenção e multas cabíveis frente a violados de direitos.

Segundo o Art. 206, do Código Penal, "Recrutar trabalhadores, mediante fraude, com o fim de levá-los para território estrangeiro" - Pena com detenção, de um a três anos e multa. O Art. 207 do Código Penal articula que: "Aliciar trabalhadores, com o fim de levá-los de uma para outra localidade do território nacional" é considerado crime com pena que consiste na detenção, de um a três anos exibida por multa.

Entende-se, portanto, que o fortalecimento do combate ao trabalho escravo a partir das indicações ora realizadas não pode ser dissociada da ampla atuação dos órgãos públicos e algumas instituições não governamentais, principalmente por movimentos 
sociais. Itanomi (2016) diz que, no Brasil, durante os últimos dez anos o índice de trabalho escravo diminuiu, sobretudo, em função da participação dos grupos que atuam na erradicação do trabalho escravo. Todavia, com o golpe político/parlamentar/jurídico/midiático iniciado em 2016, os conflitos e barbárie no campo brasileiro seguem vigentes, assim como a estratégia de alteração da conceituação de trabalho escravo e escravidão contemporânea como apregoado na Portaria 1.129 do Ministério do Trabalho de outubro de 2017.

\section{MINAS GERAIS, RETRATO DO TRABALHO ESCRAVO NO CAMPO}

De acordo com IBGE (2010), Minas Gerais possui em sua unidade federativa 853 municípios, sendo o estado brasileiro com maior número de municípios emancipados do Brasil. De acordo com a Comissão Pastoral da Terra, nestes últimos 15 anos, aproximadamente $9 \%$ desses municípios há registro de trabalho escravo no campo. No mapa a seguir, pode-se evidenciar os municípios que obtiveram registro de trabalhadores escravos no campo.

Mapa 1: No trabalhadores escravos no campo em Minas Gerais, 2000 a 2015.

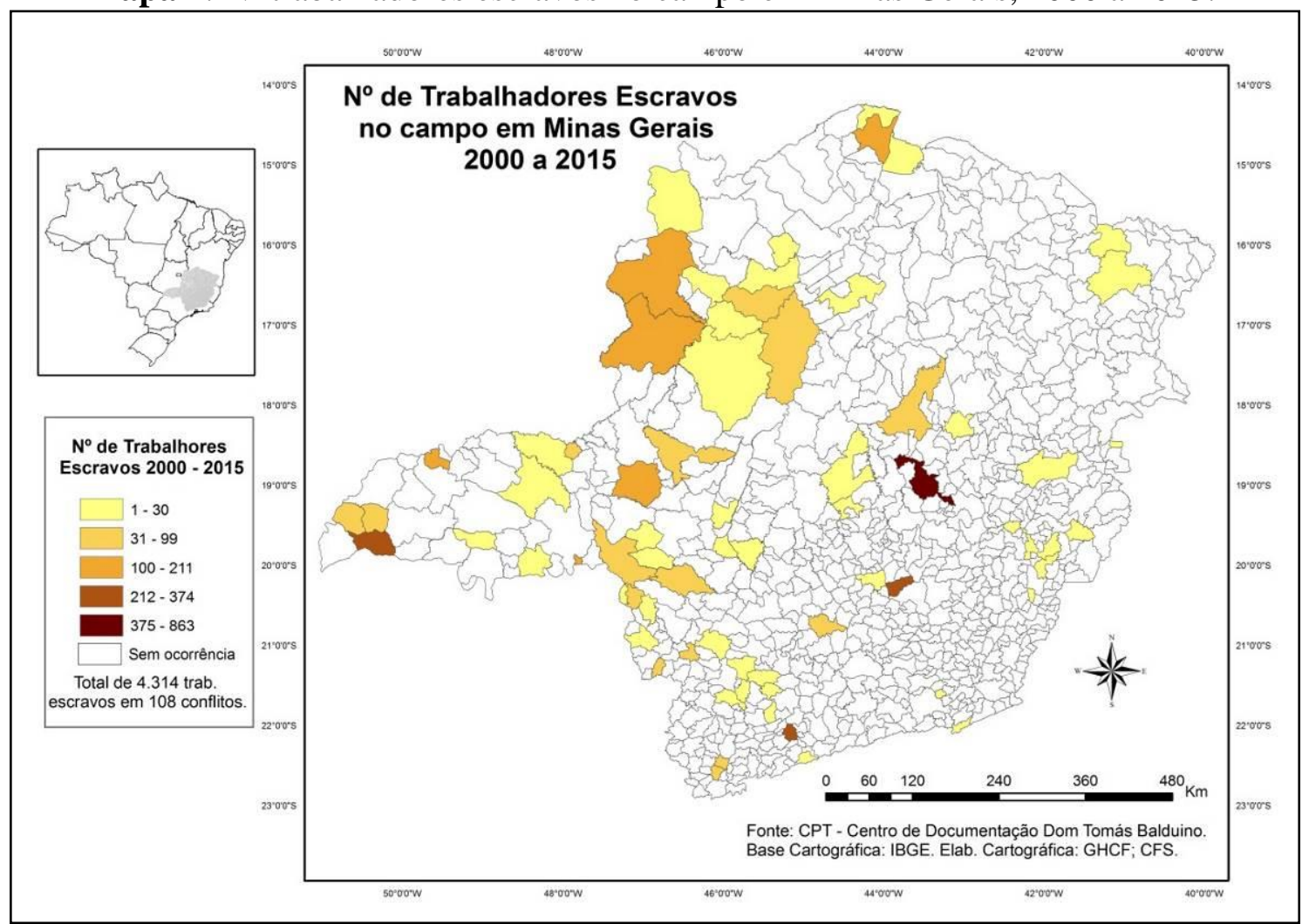

Fonte: CPT (2000 a 2015). Fonte: Os autores.

Conforme o mapa há presença de trabalho escravo, predominantemente no Sul de Minas, Triângulo Mineiro, Noroeste e Norte de Minas. Os dados revelam que nas regiões: Noroeste e Triângulo Mineiro a presença é maior. Nestas áreas, a presença da agropecuária, agroindústria entre outras, são muito comuns. Ainda de acordo com os dados da CPT, durante 2000 a 2015, as atividades como: cultivo de café, cana-de-açúcar e carvoaria foram às atividades que mais se utilizaram de mão de obra escravo no estado. 
Ressalta-se que essas atividades do campo sempre dependem de mão de obra, não necessariamente qualificada. Por isso, há um grande fluxo migratório para essas regiões, principalmente de pessoas com baixa qualificação.

A Comissão Pastoral da Terra registrou no período de 2000 a 2015, cerca de 4 mil trabalhadores resgatados em Minas Gerais, em condição análoga à de escravo, sendo que 69 desses trabalhadores eram menores. A tabela a seguir apresenta todos os municípios mineiros em que se constatou a ocorrência de trabalho escravo no campo entre o período supracitado, seguido pelo de ocorrências, número de trabalhadores escravos, números de trabalhadores menores, número de trabalhadores libertos, bem como o tipo de trabalho.

Tabela 1: $\mathrm{N}^{\mathrm{o}}$ de Trabalhadores Escravos no campo por municípios - Minas Gerais, 2000 a 2015.

\begin{tabular}{|c|c|c|c|c|c|}
\hline Municípios & Ocorrências & $\begin{array}{l}\text { No }^{\circ} \text { Trab. } \\
\text { Escravos }\end{array}$ & $\begin{array}{c}\mathbf{N}^{\circ} . \text { de } \\
\text { Menores }\end{array}$ & $\begin{array}{l}\mathbf{N}^{\circ} \text { Trab. } \\
\text { Libertos }\end{array}$ & Tipo de Trabalho \\
\hline Conceição do Mato Dentro & 1 & 863 & & 6 & Mineração \\
\hline Iturama & 1 & 374 & & 374 & Cana-de-açúcar \\
\hline Carmo de Minas & 2 & 325 & & 41 & Café \\
\hline Itabirito & 1 & 309 & & 25 & Mineração de ferro \\
\hline Patrocínio & 3 & 211 & 2 & 69 & Café \\
\hline Capinópolis & 1 & 207 & & 207 & Cana-de-açúcar \\
\hline Paracatu & 7 & 206 & & 201 & $\begin{array}{c}\text { Carvoaria, Feijão, Pecuária } \\
\text { e Cana-de-açúcar }\end{array}$ \\
\hline Delta & 1 & 170 & & & Cana-de-açúcar \\
\hline Unaí & 5 & 144 & 16 & 144 & $\begin{array}{c}\text { Carvoaria, Feijão e } \\
\text { Pecuária. } \\
\end{array}$ \\
\hline Manga & 1 & 142 & 9 & 142 & Lavoura de sementes \\
\hline Limeira do Oeste & 1 & 99 & & 99 & Cultivo de cana de açúcar \\
\hline Cláudio & 1 & 80 & & 80 & Cana-de-açúcar \\
\hline Buritizeiro & 3 & 69 & & 52 & Sem Informação \\
\hline Nova Resende & 1 & 60 & 6 & 60 & Café \\
\hline Ibiraci & 3 & 57 & 6 & 57 & Café \\
\hline Santa Fé de Minas & 3 & 56 & 6 & 43 & Carvoaria \\
\hline São Roque de Minas & 1 & 49 & & 49 & Colheita de café \\
\hline Estiva & 2 & 46 & 1 & 46 & Morango \\
\hline Oliveira & 3 & 46 & 2 & 46 & Café \\
\hline Cascalho Rico & 1 & 40 & & & Café \\
\hline Municípios & Ocorrências & $\begin{array}{l}N^{0} \text { Trab. } \\
\text { Escravos } \\
\end{array}$ & $\begin{array}{c}\mathbf{N}^{0} . \text { de } \\
\text { Menores } \\
\end{array}$ & $\begin{array}{l}\mathbf{N}^{\circ} \text { Trab. } \\
\text { Libertos }\end{array}$ & Tipo de Trabalho \\
\hline Diamantina & 1 & 40 & & 40 & Mineração \\
\hline Cambuí & 1 & 39 & 8 & 39 & Morango \\
\hline Patos de Minas & 1 & 39 & & 39 & Café \\
\hline Guaranésia & 1 & 33 & & 33 & Cana-de-açúcar \\
\hline Sacramento & 1 & 33 & & 33 & Soja \\
\hline União de Minas & 1 & 31 & 2 & 31 & Seringueira \\
\hline
\end{tabular}




\begin{tabular}{|c|c|c|c|c|c|}
\hline Machado & 2 & 30 & & 30 & Café e Mineração de Ferro \\
\hline Bonfinópolis de Minas & 4 & 27 & 1 & 23 & Carvoaria \\
\hline Campos Gerais & 1 & 27 & & 27 & Café \\
\hline Carmo do Rio Claro & 1 & 27 & & 27 & Café \\
\hline João Pinheiro & 5 & 26 & & 26 & Carvoaria \\
\hline Buritis & 4 & 24 & 2 & 24 & $\begin{array}{c}\text { Eucalipto, Carvoaria e } \\
\text { Pecuária. }\end{array}$ \\
\hline Claraval & 1 & 24 & & & Sem Informação \\
\hline Luz & 1 & 24 & & 24 & Lavoura de café \\
\hline Comendador Gomes & 1 & 23 & & 23 & Laranja \\
\hline São João do Manhuaçu & 1 & 22 & & 22 & Colheita de café \\
\hline Caratinga & 1 & 20 & & 20 & Café \\
\hline Cássia & 1 & 20 & & 20 & Café \\
\hline Matias Cardoso & 2 & 18 & & 18 & Carvão vegetal \\
\hline Pedra Azul & 2 & 18 & & 18 & Carvoaria \\
\hline Paraguaçu & 1 & 17 & & 17 & Café \\
\hline São Gotardo & 1 & 14 & & 14 & Cultivo de café \\
\hline Araguari & 1 & 13 & & 13 & Tomate \\
\hline Coronel Pacheco & 1 & 11 & & 11 & Eucalipto \\
\hline Curvelo & 1 & 11 & & 46 & Carvoaria \\
\hline Jequitinhonha & 2 & 11 & & 11 & Carvoaria \\
\hline Juvenília & 1 & 11 & & 11 & Sem Informação \\
\hline Simonésia & 1 & 11 & & 11 & Café \\
\hline Brasilândia de Minas & 1 & 10 & & 10 & Carvoaria \\
\hline Coração de Jesus & 1 & 10 & & 10 & Carvoaria \\
\hline Serro & 1 & 9 & & 9 & Pecuária \\
\hline Brumadinho & 1 & 8 & & 8 & Eucalipto \\
\hline Pintópolis & 2 & 8 & & 4 & Carvoaria \\
\hline São Romão & 1 & 8 & & 8 & Carvoaria \\
\hline São Sebastião do Paraíso & 1 & 8 & & 8 & Cana-de-açúcar \\
\hline Araxá & 1 & 7 & & 7 & Carvoaria \\
\hline Córrego Danta & 1 & 7 & & 7 & Café \\
\hline Três Pontas & 1 & 7 & & 7 & Cultivo de café \\
\hline Municípios & Ocorrências & $\begin{array}{l}\mathrm{N}^{0} \text { Trab. } \\
\text { Escravos }\end{array}$ & $\begin{array}{c}\mathbf{N}^{0} \text {. de } \\
\text { Menores }\end{array}$ & $\begin{array}{l}N^{0} \text { Trab. } \\
\text { Libertos }\end{array}$ & Tipo de Trabalho \\
\hline Chiador & 1 & 6 & & 6 & Limpeza de pasto \\
\hline Conceição das Alagoas & 1 & 6 & & 6 & Olaria \\
\hline Tapira & 1 & 6 & & 6 & Carvoaria \\
\hline Nova Belém & 1 & 4 & & 4 & Desmatamento \\
\hline Passa Quatro & 1 & 3 & & 3 & Abacate \\
\hline Rio Vermelho & 1 & 2 & & 2 & Mineração - Pedras \\
\hline
\end{tabular}




\begin{tabular}{l|c|c|c|c|c}
\hline Uberlândia & 1 & 2 & 8 & 2 & Pecuária \\
\hline Varginha & 2 & 2 & & 2 & Pecuária \\
\hline Campanha & 1 & 1 & & 1 & Café e cana-de-açúcar \\
\hline Governador Valadares & 1 & 1 & & 1 & Pecuária \\
\hline Paraopeba & 1 & 1 & & 1 & Pecuária \\
\hline Pocrane & 1 & 1 & & 1 & Pecuária \\
\hline \multicolumn{1}{c|}{ Total } & $\mathbf{1 0 8}$ & $\mathbf{4 . 3 1 4}$ & $\mathbf{6 9}$ & $\mathbf{2 . 5 0 5}$ & - \\
\hline
\end{tabular}

Fonte: CPT - Centro de Documentação Dom Tomás Balduino. Org. Os autores.

O município de Conceição do Mato Dentro localizado na região central de Minas foi o que mais concentrou trabalhadores escravos. A atividade envolvida foi à mineração, envolvendo 863 trabalhadores em situação de escravidão, com a representação de $20 \%$ em Minas Gerais e 1,14\% representação no cenário nacional; seguido por Iturama com 374 trabalhadores escravos envolvidos na produção da Cana-de-açúcar, Carmo de Minas com 325 trabalhadores escravos envolvidos na produção de café e Itabirito que concentro 309 trabalhadores escravos na mineração de ferro. Enquanto isso, na outra ponta da tabela, os municípios de Campanha, Governador Valadares, Paraopeba e Pocrane foram os municípios com menores números de trabalhadores envolvidos cerca de 1 trabalhador por ocorrência.

Embora, historicamente a mineração tenha obtido o maior número de trabalhadores escravos, o número de ocorrências é pequeno em relação a essa atividade. As principais atividades que mais envolveram trabalhadores foram: a pecuária, carvoaria, cultura do café, cultivo de cana-de-açúcar e mineração nas ocorrências registradas nesses últimos 15 anos.

Muitos dos casos de trabalho escravo no campo estão atrelados à chamada "escravidão por dívida" na qual Martins (1986) aponta que o patrão aliciava os trabalhadores ao forcarem os mesmos a assumirem dívidas, manipulação de taxas cambiais, juros pelo adiantamento do salário e por compras no armazém controlado pelos próprios patrões.

A partir desse cenário, o gráfico a seguir registra-se as atividades que envolvem mão de obra escrava em Minas Gerais. 
Gráfico 1: Atividades que envolveram mão de obra escrava no campo, Minas Gerais2000 a 2015.

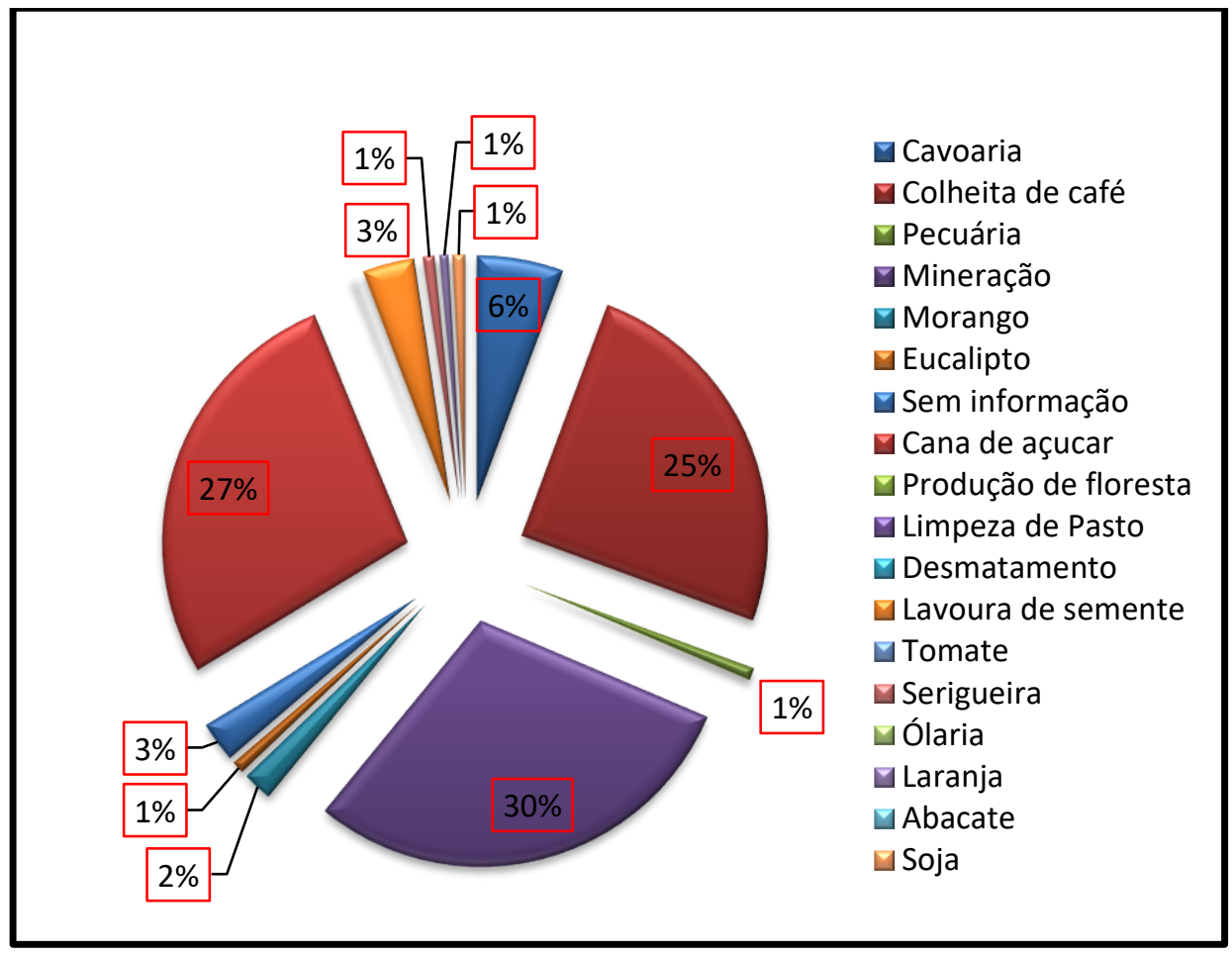

Fonte: CPT - Centro de Documentação Dom Tomás Balduino. Org. Os autores.

Observa-se que a mineração possui o maior número de trabalhadores, cerca de $30 \%$, sendo os municípios de Conceição do Mato Dentro, Diamantina, Itabirito, Machado e Rio Vermelho, responsáveis por essa posição. Em segundo posição, a atividade produção da cana de açúcar tem $27 \%$ dos trabalhadores e envolveram os municípios de Campanha, Capinópolis, Delta, Guaranésia, Iturama, Limeira do Oeste, Paracatu e São Sebastião do Paraíso.

A colheita do café é uma das atividades que envolveram mão de obra escrava, muito desses trabalhadores saem de regiões distantes tais como o do Vale do Jequitinhonha-MG e da região Nordeste. Como pode-se perceber no gráfico, essa atividade além de oferecer oferta de trabalho, também assume $25 \%$ dos trabalhadores escravos em Minas Gerais, com destaque para os municípios de Campanha, Campos Gerais, Caratinga, Carmo de Minas, Carmo do Rio Claro, Santa Luzia, Cássia, Córrego Dantas, Ibiraci, Luz, Machado, Nova Resende, Oliveira, Paraguaçu, Patos de Minas, Patrocínio, São Gotardo, São João do Manhuaçu, São Roque de Minas, Simonésia e Três Pontas.

Embora essas três atividades econômicas concentrem os maiores percentuais de trabalhadores em condições análogas à escravos, pode-se perceber no gráfico também a diversidade de atividades envolvendo tais trabalhadores escravos. Assim, pode-se evidenciar que tal problemática está territorializada nas áreas rurais e urbanas conforme registrou-se no gráfico a seguir. 
Gráfico 2: Relação quantitativa dos trabalhadores escravos resgato no campo e nas Cidades, Minas Gerais - 2000 a 2015.

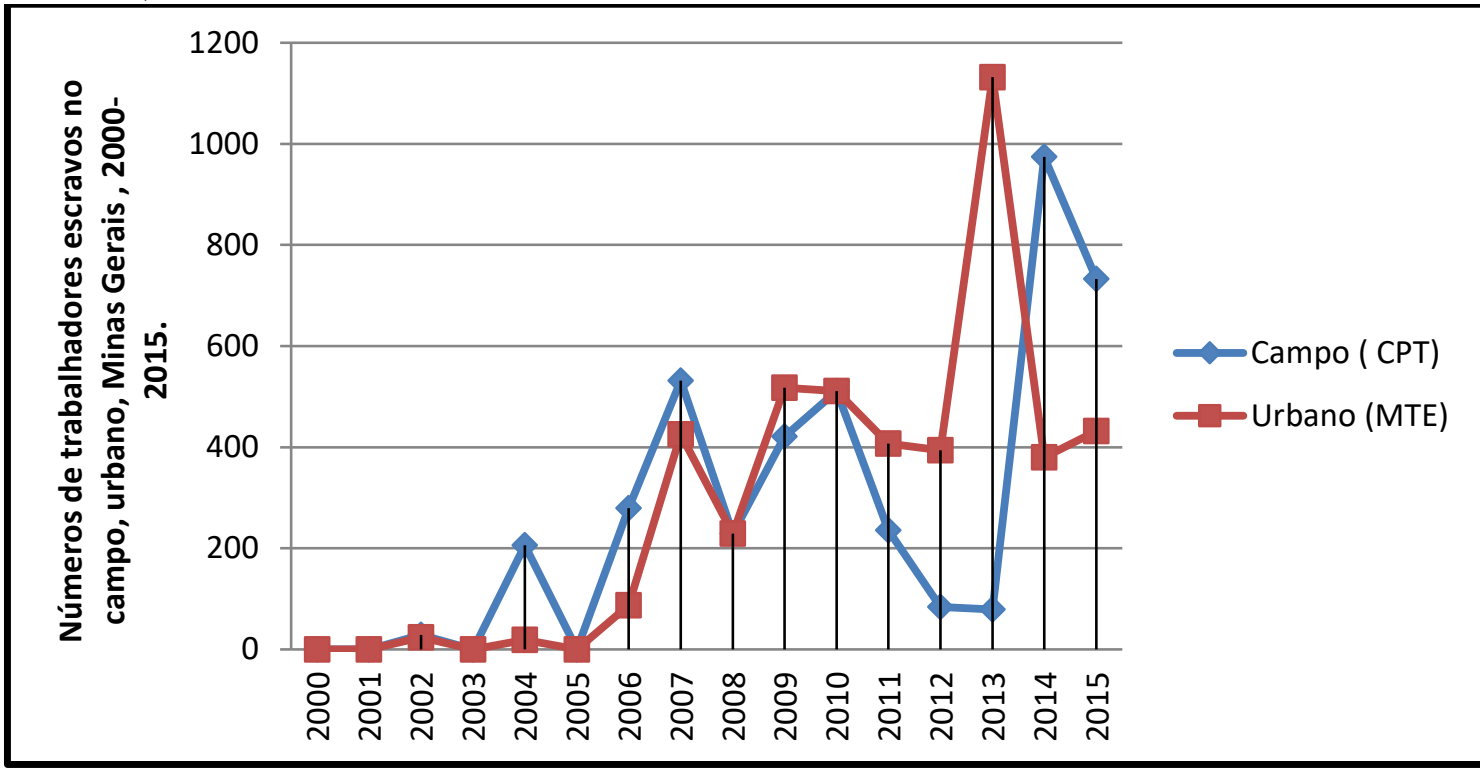

Fonte: MTE - Secretaria se Inspeção do Trabalho. CPT - Centro de Documentação Dom Tomás Balduino. Org. Os autores.

Pode-se observar no gráfico 2, que entre 2000 e 2003 os números de trabalhadores escravos praticamente seguiam estáveis com poucas ocorrências, já em meados de 2004, houve um significativo aumento nas ocorrências, sobretudo, no campo. E a partir de 2005 pode-se verificar um aumento com algumas oscilações, reflexo da contrarreforma agrária em detrimento do apoio massivo ao agronegócio (OLIVEIRA, 2010).

Constata-se ainda uma regressão no número de trabalhadores escravos no campo, no período de 2010 e 2013, porém, os casos de trabalhadores escravos no setor urbano cresceram, principalmente no ano de 2013, onde os números foram maiores do que os registros no campo. E, conforme os dados fornecidos pelo MTE, no ano de 2013 foram registrados 1.229 trabalhadores em situação análoga à escravos, sendo que a atividade da construção civil lidera os indicadores; e, estima-se que tais números são a ponta de uma perversa lógica econômica e territorial mundializada.

\section{MINAS GERAIS E O TRABALHO ESCRAVO NAS CIDADES}

Em relação ao trabalho escravo nas cidades de Minas Gerais, cabe salientar a indissociabilidade com a expansão da urbanização brasileira como um fenômeno recente, conforme apregoa Santos (2009). Assim, evidencia-se que a formação crescente dos centros urbanos brasileiros surgiu em meados de 1940.

Neste período a população brasileira concentrava-se no meio rural. E, de certo modo, a partir de 1970, houve uma inversão desse quadro a partir de uma política de expulsão da população rural para as cidades. Tal crescimento populacional nos centros urbanos mineiros não foi diferente dos demais municípios e regiões do país.

Na visão de Santos (2000), o espaço urbano como reprodutor do capital ora pode concentrar riquezas, ora pobreza. Neste sentido, Minas Gerais, na década de 1970, passou pelo chamado milagre econômico, com o crescimento de seus centros urbano-industriais e, consequentemente, a territorialização das diferentes desigualdades. 
A partir desse breve resgate histórico, reafirma-se o trabalho escravo como um fenômeno social e territorial que atinge tanto o campo quanto as cidades mineiras. No mapa a seguir, pode-se evidenciar a distribuição dos trabalhadores escravos nas áreas urbanas de Minas Gerais conforme constatado pelo MTE.

Mapa 2: $\mathrm{N}^{\circ}$ de trabalhadores escravos resgatados nas áreas urbanas em Minas Gerais $2000{\text { a } 2015^{7}}^{7}$

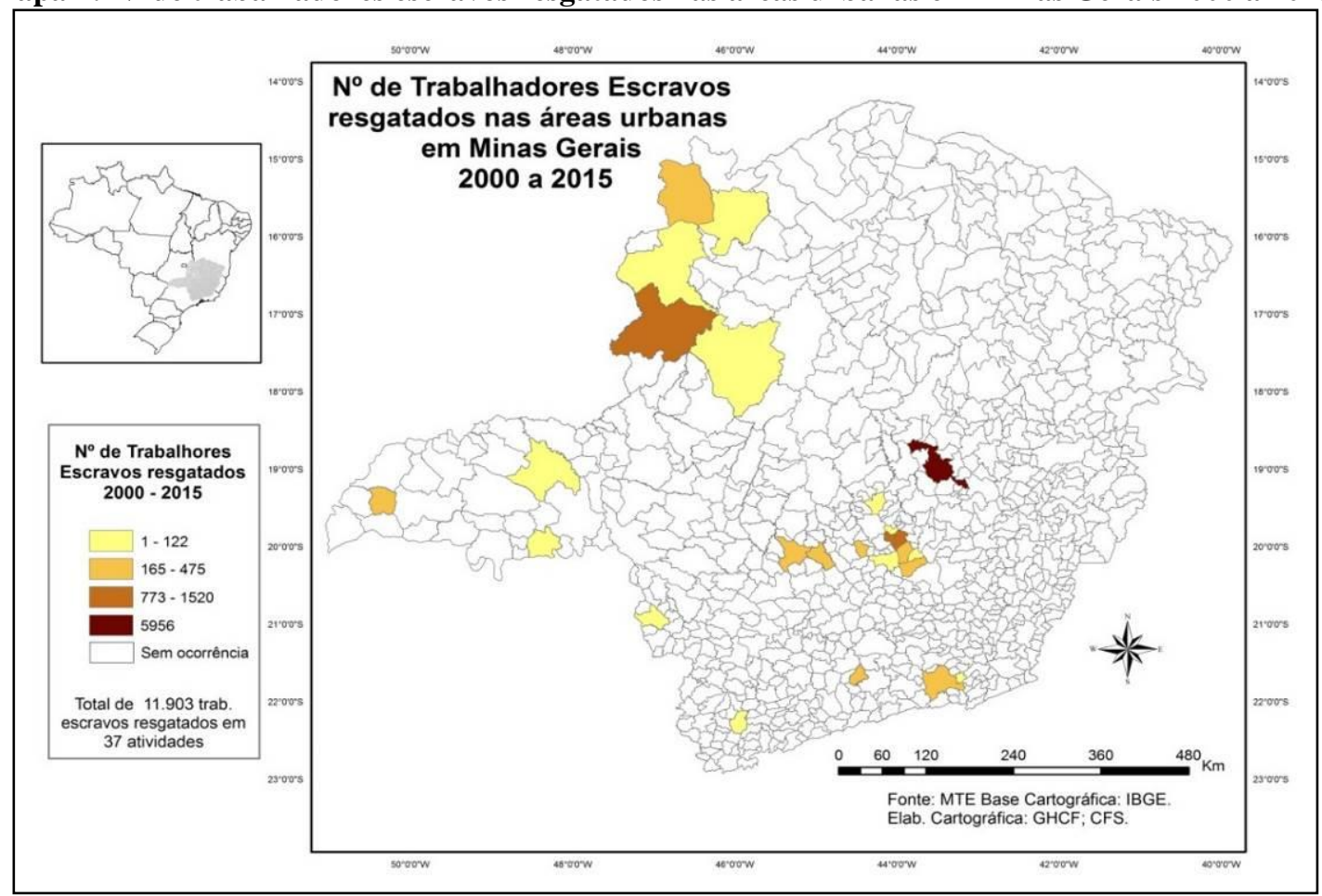

Fonte: MTE - Secretaria se Inspeção do Trabalho. Org. Os autores.

De acordo com os dados do MTE, mais de 11 mil trabalhadores foram regatados nas áreas urbanas de Minas Gerais. A construção civil foi à atividade que mais absorveu mão de obra escrava durante esses 15 anos analisados. Destacam-se os municípios de Belo Horizonte, Uberlândia, Juiz de Fora, Sete Lagoas, Brumadinho, etc.

$\mathrm{Na}$ sequência, pode-se destacar as atividades no comércio, transporte, obras e fabricação de produtos utilizando trabalhadores escravo nas cidades, conforme dados do MTE. Somente no município de São Vicente de Minas, na região Sul do estado, foram resgatados 348 trabalhadores, que exerciam atividades no comércio atacadista.

Ainda de acordo com o MTE, mais da metade dos trabalhadores encontrados em situação análoga à escravidão (53\%) foi encontrada nas atividades que envolveram a construção civil, principalmente nas construções de edifícios, rodovias, estações, etc. Em segundo lugar, $25 \%$ lidavam com obras, que se assemelham com a construção civil, porém, os trabalhadores envolvidos exercem atividades diferentes, como a parte burocrática, administrativa, engenharia, etc.

Já o comércio envolveu 10\% desses trabalhadores escravos, sendo que as redes atacadistas, varejistas, restaurantes e lojas são responsáveis por essa colocação, no mais, os meios de transporte abarcam 3\% de envolvimento, em sequência as fábricas de produtos, com $4 \%$. Embora seja menor a participação de trabalhadores escravos nas parcelas de confecção, fotocópias, assistência e aluguel de máquinas, essas atividades envolveram cerca de 5\% dos resgatados em Minas Gerais pelo MTE. 


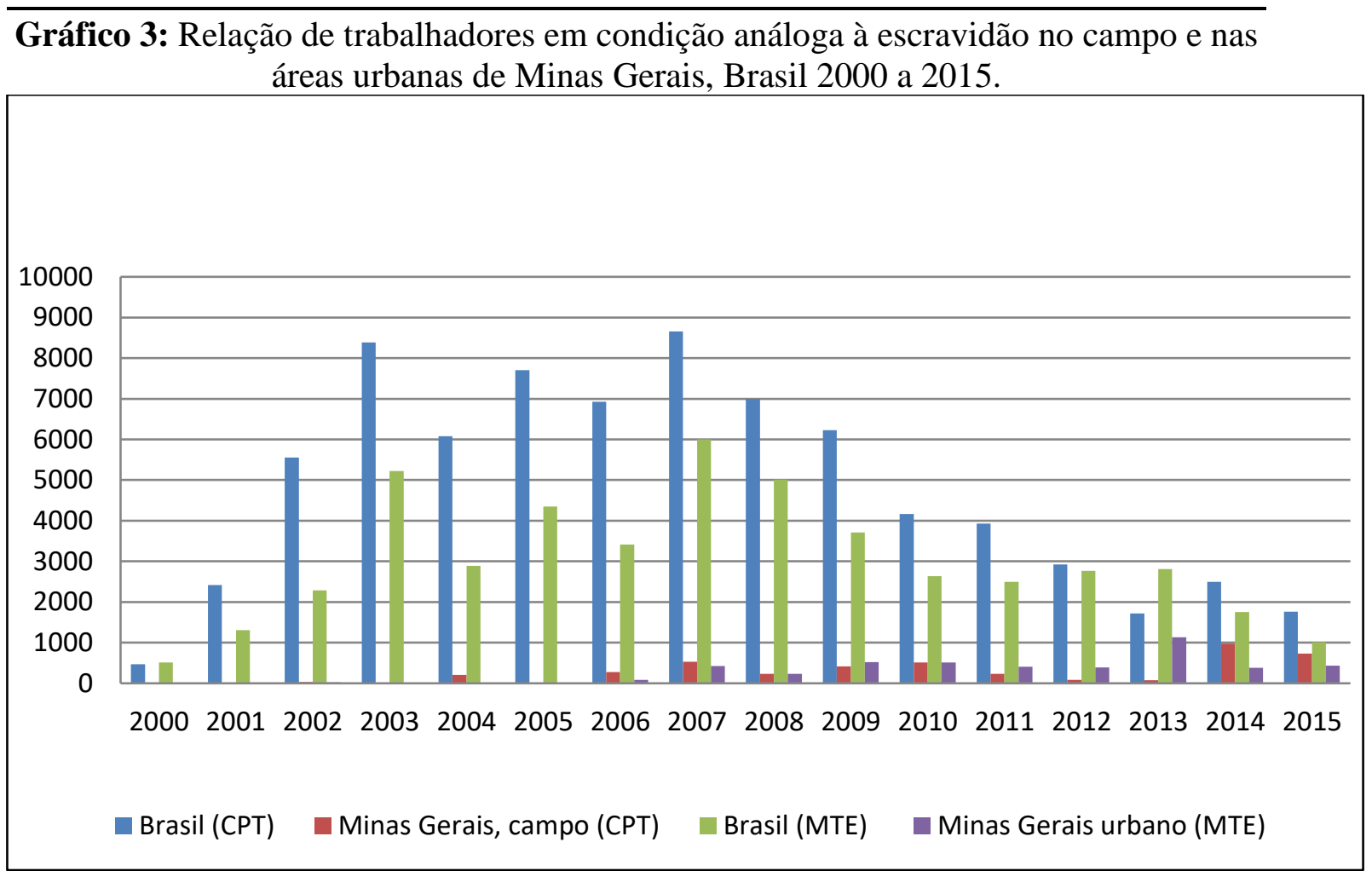

Fonte: MTE - Secretaria se Inspeção do Trabalho. CPT-Centro de Documentação Dom Tomás Balduino. Org.: Os autores.

Conforme a ONG Repórter Brasil (2016), desde 1995, mais de 50 mil trabalhadores foram resgatados em condição análoga à escravidão no país, sendo o estado de Minas Gerais responsável por mais de $8 \%$ desses trabalhadores.

\section{NORTE DE MINAS E O TRABALHO ESCRAVO NO CAMPO}

A região do Norte de Minas ${ }^{8}$ é palco de uma construção social, política, econômica e cultural que teve início desde os primórdios da ocupação territorial de Minas. Trata-se da maior mesorregião de Minas Gerais. Gonçalves (1999) indica que a apropriação dessa parte de Minas teve como fundamento a formação de latifúndios coloniais.

Nessa mesorregião concentraram-se os maiores latifúndios do período colonial, proporcionando a expansão da pecuária, bem como o escoamento das demais produções através do Rio São Francisco. Gonçalves (1999, p. 26) diz que "os Gerais, ou seja, as terras públicas das chapadas dos sertões do Norte de Minas se tornaram particulares, seja pelas mãos do Estado, através de

contrato de concessão para o uso de grandes plantações de eucalipto, seja pela apropriação à mão grande". Esse modelo econômico desenvolvido pela região Norte de Minas afetou de todas as maneiras a sociedade e o ambiente.

Moura (2007, p. 5) coloca que "esse problema herdado da época colonial afeta consideravelmente a questão agrária nas épocas monárquica e republicana. $\mathrm{O}$ excesso de terras em mãos de poucos”. Desde então, o Norte de Minas registra uma contraditória e desigual ocupação fundiária.

O Cerrado, bioma do Norte de Minas, aos poucos foi sendo consumido pelo modelo de desenvolvimento imposto na região, substituindo a vegetação por eucaliptos e 
pasto para pecuária, bem como mineração. Coube, assim, aos gerazeiros, vazanteiros, catingueiros, entre outros povos a resistência. E, conforme os dados da CPT, o Norte de Minas concentrou no período de 2000 a 2015 cerca de 140 conflitos por terra, envolvendo 22.638 famílias. Além disso, representa cerca de 12\% do total de trabalhadores encontrados em situação análoga à escravidão, envolvendo 14 conflitos (FERREIRA; SILVA; SILVA, 2017).

Girardi et al. (2014) acrescentam que nessa região os indicadores de vulnerabilidade para o aliciamento de trabalhadores escravos são elevados. Assim como na região Nordeste do Brasil, sobretudo, em função dos baixos indicadores socioeconômicos. A partir dessas reflexões, o mapa a seguir apresenta justamente os dados inerentes aos registros de trabalhos escravos no Norte de Minas entre 2000 a 2015.

Mapa 3: $\mathbf{N}^{\circ}$ de trabalhadores escravos no Norte de Minas Gerais 2000 a 2015.

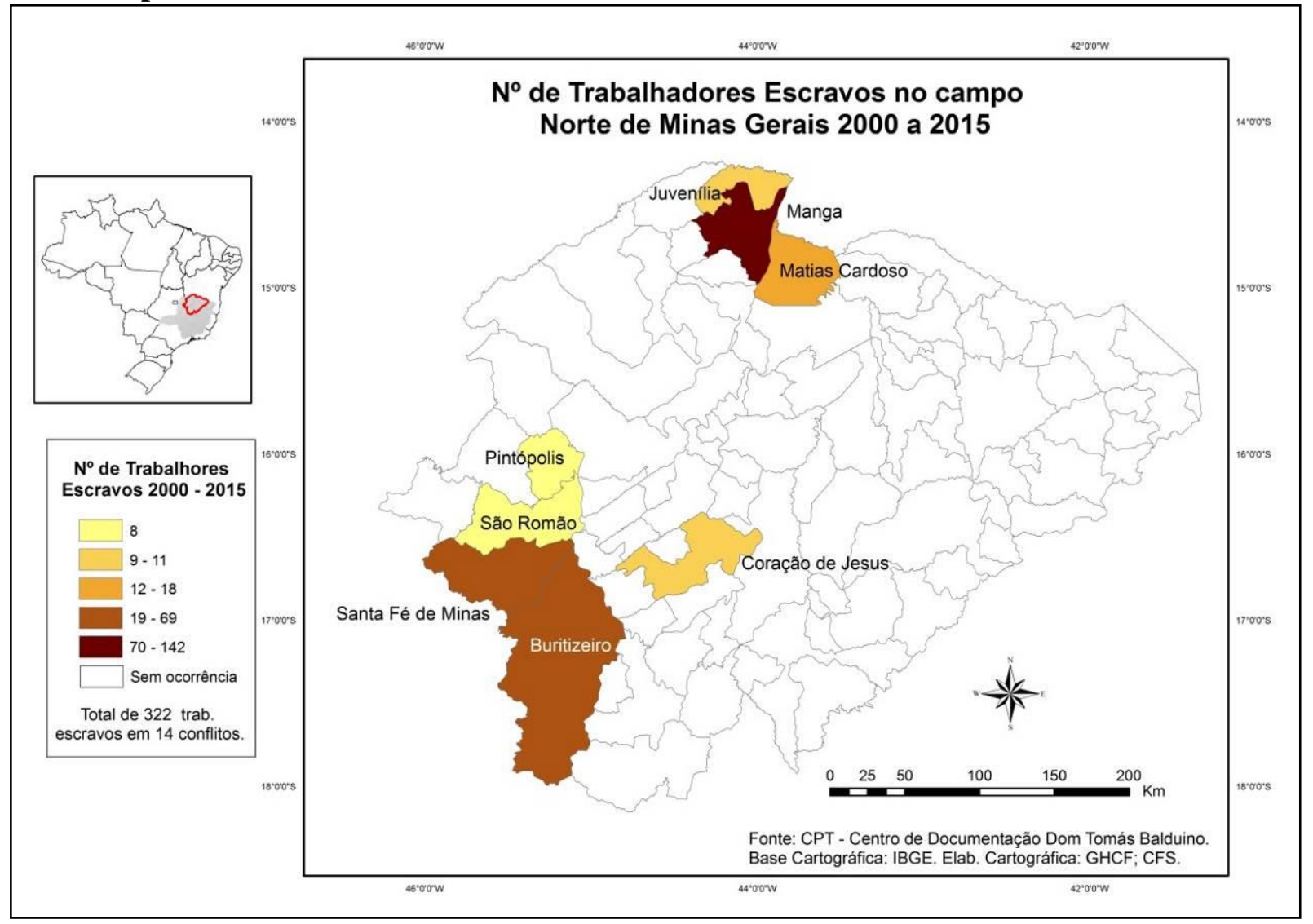

Fonte: CPT - Centro de Documentação Dom Tomás Balduino. Org.: Os autores.

A leitura do mapa nos permite evidenciar alguns municípios do Norte de Minas, tais como Manga, no extremo Norte, que faz divisa com o estado da Bahia, onde foram descobertos 142 trabalhadores escravos em três ocorrências. Já os municípios Buritizeiro e Santa Fé de Minas registraram 69 e 56 trabalhadores escravos, respectivamente, no período analisado. Em Matias Cardoso, foram registrados 18 trabalhadores escravos; nos municípios de Juvenília, Coração de Jesus, São Romão e Pintópolis, respectivamente: 11, 10,8 e 8 trabalhadores em situação análoga à escravidão.

$\mathrm{Na}$ tabela a seguir sistematizamos os dados ora apresentados, evidenciando os menores envolvidos, bem como os trabalhadores libertos e as respectivas atividades executadas nessas ocorrências territorializadas no Norte de Minas Gerais. 


\begin{tabular}{l|c|c|c|c|c}
\hline \multicolumn{6}{c}{ Tabela 4: $\mathbf{N}^{\mathbf{o}}$ de trabalhadores escravos no campo - Norte de Minas Gerais 2000 a 2015.} \\
\hline Municípios & Ocorrências & $\begin{array}{c}\mathbf{N}^{\mathbf{0}} \text { Trab. } \\
\text { Escravos }\end{array}$ & $\begin{array}{c}\mathbf{N}^{\mathbf{0}} \text { de } \\
\text { Menores }\end{array}$ & $\begin{array}{c}\mathbf{N}^{\mathbf{0}} \text { Trab. } \\
\text { Libertos }\end{array}$ & Tipo de Trabalho \\
\hline Buritizeiro & 03 & 69 & 0 & 52 & Sem Informação \\
\hline Coração de Jesus & 01 & 10 & 0 & 10 & Carvoaria \\
\hline Santa Fé de Minas & 03 & 56 & 06 & 43 & Carvoaria \\
\hline Pintópolis & 02 & 08 & 0 & 04 & Carvoaria \\
\hline São Romão & 01 & 08 & 0 & 08 & Carvoaria \\
\hline Manga & 01 & 142 & 09 & 142 & Lavoura de sementes \\
\hline Juvenília & 01 & 11 & 0 & 11 & Sem Informação \\
\hline Matias Cardoso & 02 & 18 & 0 & 18 & Carvão vegetal \\
\hline Total & $\mathbf{1 4}$ & $\mathbf{3 2 2}$ & $\mathbf{1 5}$ & $\mathbf{2 8 8}$ & - \\
\hline
\end{tabular}

Fonte: CPT - Centro de Documentação Dom Tomás Balduino. Org.: Os autores.

A partir dessas análises, pode-se afirmar que o Norte de Minas representa $12 \%$ das ocorrências de trabalhadores escravos no campo em Minas Gerais e 7\% dos números de trabalhadores em condição análoga à de escravidão no país. Somente o município de Manga representa 44\% dos trabalhadores escravos no Norte de Minas e 3\% no estado de Minas Gerais, sobretudo, nas lavouras de sementes.

A atividade de carvoaria no Norte de Minas está atrelada ao eucalipto e Cerrado, e aparece na segunda colocação, totalizando o montante de $31 \%$ dos trabalhadores nessa atividade. Nos municípios de Manga e Santa Fé de Minas, foram registrados 15 trabalhadores escravos menores de 18 anos. Trata-se de uma situação grave registrada pela CPT e outros órgãos governamentais.

No município de Buritizeiro, considerado o maior município em extensão territorial do Norte de Minas Gerais, e no município de Juvenília, embora seja possível constatar um número significativo de trabalhadores, não é possível identificar as atividades nos dados oriundos da CPT.

Assim, o modelo insustentável para o Norte de Minas e outras regiões do Brasil segue cunhado pelo agronegócio e suas perversas práticas coloniais. Gonçalves (1999) reafirma que a queima do Cerrado e dos próprios eucaliptos faz com que os impactos sobre os recursos hídricos sejam sentidos pelos camponeses nas suas práticas na terra de trabalho e vida.

Por isso, vale reafirmar que tal modelo desenvolvimentista implementado no Norte de Minas, através das grandes plantações de eucaliptos, projetos de irrigação e outros empreendimentos do agronegócio e minerários, alavanca os conflitos por terra, água e trabalhistas no Norte de Minas e no Brasil.

\section{CONSIDERAÇÕES FINAIS}

Neste estudo, foram analisados os casos de trabalhadores escravos no estado de Minas Gerais, entre o período de 2000 a 2015. Assim, foi possível identificar os municípios e atividades que concentram o maior número que de trabalhadores escravos; como exemplo, destaca-se o município de Conceição do Mato Dentro, na mesorregião metropolitana de Belo Horizonte, representando 20\% dos casos em Minas Gerais e 1,14\% em escala nacional.

Os dados fornecidos pelo MTE e pela CPT apontaram que 70 municípios em Minas Gerais obtiveram registro de trabalhadores escravos no campo entre o período de 2000 a 
2015, totalizando 4.314 trabalhadores envolvidos em 108 ocorrências/conflitos e 17 atividades econômicas, com destaque para: cultivo de café, cana-de-açúcar, carvoaria, pecuária, mineração, etc.

$\mathrm{Na}$ mesorregião Norte de Minas, constata-se o trabalho escravo no campo, principalmente entre os municípios de Juvenília, Matias Cardoso, Coração de Jesus, Santa Fé de Minas, Manga, Buritizeiro, Pintópolis e São Romão, estes municípios apresentaram envolvimento de $12 \%$ de trabalhadores escravos no campo de Minas Gerais, sobretudo, nas atividades de carvoaria e lavouras.

Os dados obtidos revelam que o Brasil tem diminuído expressivamente casos de trabalhadores escravos, no entanto, o estado de Minas Gerais segue com índices elevados tantos nas ocorrências de trabalhadores escravos no campo quantos nas áreas urbanas, nisto os órgãos e instituições como a Comissão Pastoral da Terra, de cunho não governamental e o Ministério do Trabalho e Emprego, visam atuar nacionalmente e regionalmente com medidas de acompanhamento, denúncias e também com estratégias para erradicação desse ato desumano e criminoso. Percebe-se, portanto, que o trabalho dessas duas instituições é de extrema importância no combate do trabalho contemporâneo.

Assim, cabe salientar que há uma perversa e contraditória Geografia do Trabalho Escravo no país, cuja aliança terra-capital e ambiental em diferentes instâncias do legislativo, executivo e judiciário seguem sendo legitimadas com práticas antidemocráticas, por isso a resistência segue vigente, assim como os conflitos.

\section{NOTAS}

1 - Essas análises estão vinculadas as pesquisas: "Atlas da questão agrária Norte Mineira" e "A questão agrária nos filmes de Adrian Cowell: a década da destruição - 1980 a 1990", desenvolvidas no âmbito do Departamento de Geociências - UNIMONTES.

2 - Lei Imperial ${ }^{\circ} 3.353$, sancionada em 13 de maio de 1888, precedida pela Lei $\mathrm{n}^{\circ} 2.040$ (Lei do Ventre Livre), de 28 de setembro de 1871, que libertou todas as crianças nascidas de pais escravos, e também pela Lei no 3.270 (Lei Saraiva-Cotegipe ou Lei dos Sexagenários), de 28 de setembro de 1885 , que regulava "a extinção gradual do elemento servil".

3 - "Alguns acadêmicos têm notória e compreensível dificuldade para dar a essa relação de trabalho o nome que lhe é mais apropriado: escravidão. Ainda que se trate, claramente, de uma relação de sujeição, que vai ao ponto de fazer o patrão supor que tem um direito absoluto ao corpo do trabalhador, além do próprio trabalho, como se vê quando este é submetido à humilhação, à tortura, ao castigo e até à morte. Essa dificuldade decorre, no meu modo de ver, de opções teóricas inadequadas ao tratamento do tema. De um lado, de uma concepção liberal e típico-ideal de capitalismo, que os impede de aceitar que o capital possa gerar outra forma de exploração do trabalho que não seja formalmente contratual e livre". (MARTINS, 1995, p. 20).

4 - A lei $n^{\circ} 601$ de 18 de setembro de 1850.

5 - Cedoc - Dom Tomás Balduino.

6 - Segundo os dados da CPT em 2016 foram regatados no Brasil 753 trabalhadores escravos em 69 conflitos sendo Minas Gerais responsáveis por 108 trabalhadores em 11 conflitos, o café foi a principal atividade que utilizou trabalhadores em condições análogas à escravidão. 
7 - Dados do Ministério do Trabalho apontam que os números de trabalhadores resgatados em 2016 no Brasil foram inferiores aos de 2015, com queda de $34 \%$.

8 - A mesorregião Norte de Minas é formada por 89 municípios, dividida em sete microrregiões: Janaúba, Januária, Montes Claros, Bocaiuva, Pirapora, Salinas e Grão Mogol. Conforme o IBGE, a estimativa da população para 2016 era de 1.735.670, dividida em uma área de $128.454,108 \mathrm{~km}^{2}$, portanto, a densidade demográfica da região é de 13,5 hab. $/ \mathrm{km}^{2}$.

\section{REFERÊNCIAS BIBLIOGRÁFICAS}

ALMEIDA, Antonio A. de. Trabalho escravo: educar para libertar. In.: FIGUEIRA, Ricardo R.; PRADI, A. A.; GALVÃO, E. M. (Orgs.). Trabalho escravo contemporâneo: estudos sobre ações e atores. Rio de Janeiro: Mauad X, 2017.

BRASIL. Constituição da República Federativa do Brasil. Brasília, DF: Senado Federal: Centro Gráfico, 1988.

Decreto-Lei 2848/1940. Brasília, DF: Presidência da República, 1940. Disponível em: <http://www.planalto.gov.br/ccivil_03/Decreto-Lei/Del2848.htm>. Acesso em: 27 fev. 2017.

COMISSÃO PASTORAL DA TERRA. Conflitos no Campo-Cadernos de 2000 a 2016. Goiânia: CPT Nacional.

FERREIRA, Gustavo H. Cepolini; SILVA, Rosilene G.; SILVA, Franciele. A. A territorialização camponesa e do agronegócio no Norte de Minas: algumas leituras preliminares. Boletim Paulista de Geografia, v. 97, p. 21-41, 2017.

FIGUEIRA, Ricardo Rezende; PRADO, Adonia Antunes. Trabalhadores denunciam o trabalho escravo. Hendu-Revista Latino-Americana de Direitos Humanos, v. 4, n. 1, 2014.

GIRARDI, Eduardo Paulon et al. Mapeamento do trabalho escravo contemporâneo no Brasil: dinâmicas recentes. Espaço e Economia. Revista Brasileira de Geografia Econômica, n. 4, 2014.

GONÇALVES, Carlos Walter Porto. As Minas e os Gerais: breve Ensaio sobre Desenvolvimento e Sustentabilidade a partir da Geografia do Norte de Minas. IV Encontro Nacional de Rede Cerrado-Montes Claros, 1999.

INATOMI, Celly Cook. A atuação do poder jurídico nas políticas de erradicação do trabalho escravo rural no Brasil Contemporâneo. Tese de Doutorado em Ciência Política. Campinas: UNICAMP, 2016.

IBGE - Instituto Brasileiro de Geografia e Estatística. PIB dos municípios do estado de $M G \quad$ em 2013. Disponível em: <http://www.sidra.ibge.gov.br/bda/tabela/protabl.asp?c=5938\&z=p\&o=31\&i=P>. Acesso em: 17 jan. 2017. 
. Estimativas da população residente no Brasil e unidades da federação com data de referência em $1^{o}$ de julho de 2015. Disponível em: $<$ ftp://ftp.ibge.gov.br/Estimativas_de_Populacao/Estimativas_2015/estimativa dou_2015_20150915.pdf>. Acesso em: 17 jan. 2017.

MARTINS, José de Souza. O cativeiro da terra. São Paulo: Hucitec, 1986.

A reprodução do capital na frente pioneira e o renascimento da escravidão no Brasil. Tempo Social - Rev. Sociol. USP, São Paulo, v. 6, n. 1-2, p. 1-25, 1994 (editado em jun. 1995).

MELO E SILVA, Cristiane Passos. Seria o Estado a besta fera da vez? In: CPT. Conflitos no Campo Brasil 2015. Goiânia: CPT Nacional, 2016.

MOURA, Antônio de Paiva. As Minas Gerais, Norte de Minas: dos Primórdios à Revolução de 1930. 2007. Disponível em: <http://www.asminasgerais.com.br/ cidadesoffine/nortearea2007>. Acesso em: 4 fev. 2017.

MTE. Lista suja do trabalho escravo. Disponível em: <http://trabalho.gov.br/trab_escravo/lista_suja.pdf>. Acesso em: 10 mai. 2017

OIT. As boas práticas da inspeção do trabalho no Brasil: a erradicação do trabalho análogo ao de escravo. Brasília: OIT, 2010.

OIT. Uma aliança global contra o trabalho forçado. Relatório Global do Seguimento da Declaração da OIT sobre os Princípios e Direitos Fundamentais no Trabalho - 2005. Disponível em: <http://www.oitbrasil.org.br/trabalho_forcado/oit/relatorio/relatorio_global2005.pdf>. Acesso em: 28 jul. 2017.

OLIVEIRA, Ariovaldo U. de. A Geografia das lutas no campo. São Paulo: Contexto, 1994.

A questão agrária no Brasil: não reforma e contrarreforma agrária no governo Lula. In.: MAGALHAES, João Paulo de Almeida. Os anos Lula, contribuições para um balanço crítico 2003-2010. Rio de Janeiro: Garamond, 2010.

ONU - Organização das Nações Unidas. Declaração Universal dos Direitos Humanos. 1948. Disponível em: <http://www.onu-brasil.org.br/documentos_ direitoshumanos.php>. Acesso em: 19 jan. 2017.

SAKAMOTO, Leonardo. "Lista de transparência" traz 349 nomes flagrados por trabalho escravo. 2016. Repórter Brasil. Disponível em: < http://reporterbrasil.org.br/ 2016/06/lista-de-transparencia-traz-349-nomes-flagrados-por-trabalho-escravo/>.

Acesso em 19/1/2017.

Trabalho Escravo no Brasil do Século XXI. Primeira edição 2006. Disponível em: 〈www.oit.org.br/node/315>. Acesso em: 26 mai. 2017. 
SANTOS, Cilícia Dias dos. A formação e produção do espaço urbano: discussões preliminares acerca da importância das cidades médias para o crescimento da rede urbana brasileira. Revista Brasileira de Gestão e Desenvolvimento Regional, v. 5.1, 2009.

SANTOS, Milton. Por uma outra globalização. Rio de Janeiro: Record, 2000. 